\title{
Sykehuspresten og meg - en ateists bekjennelser
}

Da jeg begynte turnustjenesten på Aker høsten 2010, visste jeg ærlig talt ikke at det fantes 24 timers presteberedskap. Et sånt kapell og noe greier regnet jeg med, men døgnberedskap? Jeg regnet med at man gikk dit hvis man ville be, og ikke så mye annet. Greit nok. Som dere skjønner, finnes jeg ikke religiøs.

\section{4 timers prestetjeneste}

Veldig fort ble det klart at prestetjenesten var aktiv. Det var lapp på gangen om tilbudet. Pasientene fikk god informasjon om tilbudet, fra leger og pleiere. Det stusset jeg over, det virket litt rart å tilby dette? Presten var jevnlig innom lungeavdelingen på besøk. Jan Gaute Sirevåg hilste varmt på meg. Det var jo hyggelig, i en ellers stresset hverdag. Etter hvert som erfaringen min økte, økte også ansvaret for pasienter og pårørende. Nedleggelsesprosessen økte presset betraktelig. Plutselig visste jeg altfor godt hvorfor det var 24 timers prestetjeneste.

Presten var en essensiell del av et tett felleskap på lungeavdelingen, et stolt felleskap med den ekstraordinære legen Sjur Humerfelt i spissen (en mann som for øvrig fortjener en egen kronikk). Vi samarbeidet godt den høsten, presten og jeg. Ofte ble de forferdeligste samtaleemner til fine samtaler. Presten var ikke redd for å snakke inn i hjertet til folk. Det var godt for en ung turnuslege å ha en trygg person med. Ikke alt var trist. Da assistentlegen forlovet seg, hvem var det som ble spurt om å utføre vielsen? Presten. Når medisinstudentene kom på visitten, hvem var med for å snakke om livets store begivenheter? Presten. Når trykket fra Oslo-prosessen ble for mye, hvem kunne de ansatte snakke med? Presten. Da vi opplevde et uventet dødsfall, hvem var det som tok seg av pårørende, den ansvarlige legen, de ansatte? Presten. Når pasienter var låst fast i langvarig konflikt med avdelingen, hvem klarte mirakuløst å låse det opp? Presten.

Utover våren fikk jeg personlig behov for presten. Det var tungt i tung psykiatri, gravid med nummer to, gift med en turnuslege og hele tiden usikker på arbeidsgiveren. I en stor prosess ble de minste glemt, og de store var opptatt med egne problemer. Alle var slitne. Ingen visste noe.

Hvem var det å snakke med? Som hadde taushetsplikt, ledererfaring og tid? Presten. Etter bare en samtale med presten var beina lettere og ryggen rettere. Jeg gikk inn med tungt hjerte og ut i strålende solskinn. Det var godt å høre at man var én blant mange som hadde hatt behov for slike samtaler dette året. Det var godt å oppleve at noen i organisasjonen fortsatt lyttet til de ansatte,

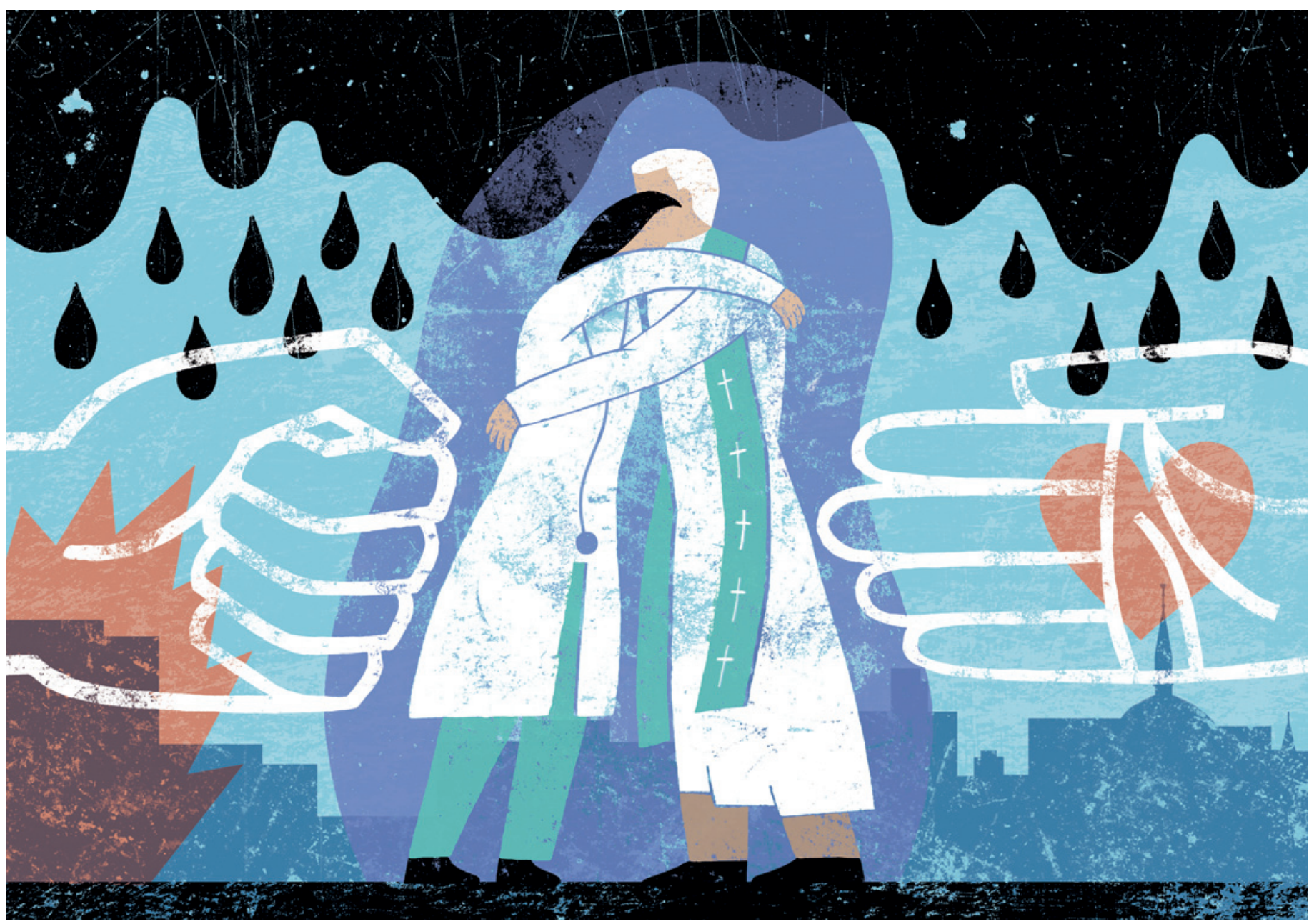


og brydde seg attpåtil. Mannen min fikk også rett som det var en hyggelig hilsen eller et klapp på ryggen fra presten. Det var fint å vite at noen passet på ham også.

\section{Den mørkeste julidagen}

En julidag gikk jeg og ventet på babyen. Da ringte jeg og takket presten for all hjelp. Det var en så hyggelig samtale at jeg tenkte jeg måtte skrive noe om denne mannen. Like etter kom den mørkeste julidagen. Bomben smalt svært nært, hele huset ristet, og jeg skvatt opp. Toåringen hadde jeg sendt på Deichmanske med barnevakten. Tanken på å miste henne røk en sikring i hodet mitt. Mannen styrtet fra jobben, og vi lette i full panikk på hver vår kant. Vi fant henne heldigvis i god behold, det mest takknemlige øyeblikket man kan tenke seg. Men kvelden, nyhetene, helikoptrene, sirenene fortsatte og fortsatte. Regnet og tordenen ga ekle ekko i sjelen helgen igjennom. Vi var så takknemlige for hellet vårt, hele familien var trygg, Men det føltes som om noe var gått i stykker dypt inne i sjelen. Ville vi noen gang bli normale? Og babyen kunne jo ikke komme ut til en slik verden. Hvem kunne man egentlig snakke med?

Den tredje dagen ringte jeg presten og gråt. Jeg husker ikke så mye av det han sa, bare at det hjalp så uendelig mye. Det var andre som hadde så stort behov, men likevel tok han seg tid til meg. Fra og med den kvelden følte jeg en dyp ro i sjelen, en ro som fortsatt er med meg. Det som gikk i stykker, vokste sterkere tilbake. Kanskje ville det skjedd uansett, men med fødselen nær trengte jeg at det skjedde fort. Man må kunne ta imot det nye livet på riktig måte. Og den prosessen tror jeg presten hjalp meg med.
Det skjer tragiske ting hele døgnet. Mennesker har angst hele døgnet. De finner ut at de må snakke med noen hele døgnet. Pårørende ringer, hele døgnet. Og da har de, hele døgnet, en erfaren, trygg person å snakke med. En som ikke må løpe videre, ikke dømmer, og ikke medisinerer bort følelsene. En som gir inntrykk av å ha uendelig med tid, uansett hvor opptatt han er. En som lytter uten å dømme. Som har taushetsplikt uten behandlingsansvar. En som formidler kjernen i ritualene vi har glemt, en som ikke er redd for følelser.

En sjelesørger.

\section{«Vi samarbeidet godt den høsten, presten og jeg»}

Prester får høre det ingen andre får høre. De ser den delen av livet som vi ikke kan, vil eller har tid til å se. Mens helsepersonell skal ta ansvar for og hjelpe pasienten, trenger en prest kun å vise omsorgsfullt nærvær og lose folk gjennom. Helsepersonell må slåss, mot systemet, mot døden, mot fortvilelsen. Presten er en sjelesørger, hans oppgave er å gjøre prosessen god. Harde endepunkter er en ting, men hvordan man bruker tiden sin frem til da, er en helt annen.

\section{Medmennesketjeneste}

Jeg vil oppfordre til refleksjon rundt prestenes rolle. Kanskje denne uvurderlige tjenesten burde vært trukket frem og brukt mer aktivt? Både i forhold til livets store overganger, død, fødsel, kriser, men også i arbeid med HMS, psykososialt miljø og tverrfaglig samarbeid, endringsarbeid, retningslinjearbeid og undervisning av studenter.

Prester er uformelle ledere og nødvendige sikkerhetsventiler i systemet. De sitter på uvurderlig kunnskap i møtet med pasienter og ansatte. Dessverre arbeider de ofte så stillferdig at man skulle tro de ikke var der. I sin ydmykhet flagger de heller ikke sin egen funksjon. De jobber ikke bare med kristendom, men med hele livet på sykehusene. De er sjelesørgere uavhengig av tro, i løpet av hele dette året har jeg ennå ikke hørt presten nevne Gud.

Som hardbarket ateist innser jeg likevel at prestene fyller en rolle i livets store og små begivenheter. De forvalter en glemt kunst, en kunnskap som mange søker etter. Jeg har lært at man rett som det er, har behov for et medmenneske. Og da er presten der. 24 timers medmennesketjeneste burde de kanskje kalt det.

Sarah Fogth Lindqvist

sarahlindqvist@gmail.com

Oslo

Sarah Foght Lindqvist (f. 1984) er turnuslege ved Oslo universitetssykehus, Aker.

Mottatt 9.11.2011, godkjent 17.11.2011. Medisinsk redaktør Erlend Hem. 